\title{
38 \\ LFG - LANDFILL GAS IN NORDIC COUNTRIES
}

Knut H. Birkeland

Energisystemer AS, Aaslyveien 9, N-3215 Sandefjord

Norway

\section{SUMMARY}

LFG- extraction systems were introduced in 1982 to the Nordic countries. Up until today there have been built 120 plants. The next few years will double the number. The energy potential will increase from 1 TWh to 2 TWh. In an environmental aspect this reduction of methane to the atmosphere can be compared to a stop of all use of private cars (ca. 10 million tons of $\mathrm{CO}_{2}$ )

\section{INTRODUCTION}

The last 15 years it has been more or less common to extract LFG - landfill gas from both closed and operating landfills. The extraction is normally founded on one or some of the arguments listed below:

- Global environmental reasons - air, earth and water pollution.

- Local environmental reasons - employers, nabours and costumers health and behaviour

- Energy recovery

- Increase the life of the landfill

The initiative to extract gas from the local landfill is normally taken by the local authorities, the landfill company or special interest groups.

It has been assumed that each Nordic country has its own policy about LFG- extraction. Each country use its own technology.

Denmark (and Norway) use automatic systems, Sweden use high speed technology, Finland use low speed technology, Norway use half automatically technology and Iceland is building traditional systems. More or less, almost all of the plants built up to this day are very traditional - to traditional. To my opinion it 
should be easy to optimise/upgrade most landfill extraction systems to be economical interesting subjects - probably except simple extraction systems which deliver raw gas direct to a district heating system.

\section{DENMARK}

In Denmark they started LFG extraction in 1982. In 1997 they have 13 plants and they estimate that 10-15 new plants will be built the next few years.

- The main reasons for extracting gas is

- Authorities demand

- Environmental reasons

- Economical benefits - earn money on the energy.

Table 1. LFG production and utilisation in Denmark (1996).

\begin{tabular}{|c|c|c|c|c|c|}
\hline $\begin{array}{c}\text { No.of } \\
\text { plants }\end{array}$ & $\begin{array}{c}\text { LFG } \\
\mathrm{m}^{3} \times 10^{6}\end{array}$ & $\begin{array}{c}\text { Heat } \\
\mathrm{GWh}\end{array}$ & $\begin{array}{c}\text { Electrisity } \\
\mathrm{GWh}\end{array}$ & $\begin{array}{c}\text { Flare } \\
\mathrm{GWh}\end{array}$ & $\begin{array}{c}\text { Total } \\
\mathrm{GWh}\end{array}$ \\
\hline 13 & $30^{*}$ & $100 * *$ & $60 * *$ & $0 ?$ & 160 \\
\hline
\end{tabular}

*Based on: $\mathrm{CH}_{4} \%=50$

** Estimated. Mostly combined heat\&power (CHP), but some are only producing electrisity.

\section{FINLAND}

In Finland they started to build LFG extraction plants just a few years ago. To day they have 8 plants in operation.

It is estimated that approximately 50 plants will be build the next few years.

They have 3 main reasons for building extraction systems:

- Authorities demand

- Reducing global emissions

- Public opinion

Table 2. LFG production and utilisation in Finland (1997).

\begin{tabular}{|c|c|c|c|c|c|}
\hline $\begin{array}{c}\text { No. of } \\
\text { plants }\end{array}$ & $\begin{array}{c}\text { LFG } \\
\mathrm{m}^{3} \times 10^{6}\end{array}$ & $\begin{array}{c}\text { Heat } \\
\mathrm{GWh}\end{array}$ & $\begin{array}{c}\text { Electrisity } \\
\mathrm{GWh}\end{array}$ & $\begin{array}{c}\text { Flare } \\
\text { GWh }\end{array}$ & $\begin{array}{c}\text { Total } \\
\mathrm{GWh}\end{array}$ \\
\hline 8 & 35 & $86 *$ & $10^{*}$ & $80^{*}$ & $176^{*}$ \\
\hline
\end{tabular}

*Based on a heat value of $5 \mathrm{kwh} / \mathrm{m}^{3}$ 


\section{ICELAND}

In Iceland they started tests with LFG extraction in 1995. From December 1996 they have one plant in operation. The gas is flared.

The gas is collected and flared because of authorities demand and of global environmental reasons.

They estimate to build 3-5 new plants the next few years..

Table 3. LFG production and utilisation in Iceland (1997).

\begin{tabular}{|c|c|c|c|c|c|}
\hline $\begin{array}{c}\text { No. of } \\
\text { plants }\end{array}$ & $\begin{array}{c}\text { LFG } \\
\mathrm{m}^{3} \times 10^{6}\end{array}$ & $\begin{array}{c}\text { Heat } \\
\mathrm{GWh}\end{array}$ & $\begin{array}{c}\text { Electricity } \\
\mathrm{GWh}\end{array}$ & $\begin{array}{l}\text { Flare } \\
\mathrm{GWh}\end{array}$ & $\begin{array}{c}\text { Total } \\
\text { GWh }\end{array}$ \\
\hline 1 & $0,85^{*}$ & 0 & 0 & 4,9 & 4,9 \\
\hline
\end{tabular}

*10 months only

If we estimate that the production in October, November and December are equal to main production, the numbers for the year 1997 is given in table 4 .

Table 4. LFG production and utilisation in Iceland - an estimate (1997).

\begin{tabular}{|c|c|c|c|c|c||}
\hline $\begin{array}{c}\text { No. of } \\
\text { plants }\end{array}$ & $\begin{array}{c}\text { LFG } \\
\mathrm{m}^{3} \times 10^{6}\end{array}$ & $\begin{array}{c}\text { Heat } \\
\text { GWh }\end{array}$ & $\begin{array}{c}\text { Electricity } \\
\text { GWh }\end{array}$ & $\begin{array}{c}\text { Flare } \\
\text { GWh }\end{array}$ & $\begin{array}{c}\text { Total } \\
\text { GWh }\end{array}$ \\
\hline 1 & 1,0 & 0 & 0 & 5,9 & 5,9 \\
\hline
\end{tabular}

\section{NORWAY}

The first plant was constructed in 1982/83, but was built in 1985 .

Most plants are build on authorities demand - because of local and global environmental reasons. Public opinion is a main reason in many cases.

Table 5. LFG production and utilisation in Norway (1997).

\begin{tabular}{|c|c|c|c|c|c|}
\hline $\begin{array}{c}\text { No. of } \\
\text { plants }\end{array}$ & $\begin{array}{c}\text { LFG } \\
\mathrm{m}^{3} \times 10^{6}\end{array}$ & $\begin{array}{c}\text { Heat } \\
\text { GWh }\end{array}$ & $\begin{array}{c}\text { Electricity } \\
\text { GWh }\end{array}$ & $\begin{array}{c}\text { Flare } \\
\text { GWh }\end{array}$ & $\begin{array}{c}\text { Total } \\
\text { GWh }\end{array}$ \\
\hline 34 & 60 & 19 & 11 & 270 & 300 \\
\hline
\end{tabular}




\section{SWEDEN}

Sweden build their first LFG extraction plant as early as in 1982/83. Since then they have built 56 plants on operating landfills and 7 on closed landfills. They are planning some 20 new plants.

Primarily LFG extraction plants are built because of global environment protection.

Totally they produce about 80 millions mê of LFG.

Table 6. LFG production and utilisation in Sweden (1996).

\begin{tabular}{|c|c|c|c|c|c|}
\hline $\begin{array}{c}\text { No. of } \\
\text { plants }\end{array}$ & $\begin{array}{c}\text { LFG } \\
\mathrm{m}^{3} \times 10^{6}\end{array}$ & $\begin{array}{c}\text { Heat } \\
\mathrm{GWh}\end{array}$ & $\begin{array}{c}\text { Electricity } \\
\text { GWh }\end{array}$ & $\begin{array}{c}\text { Flare } \\
\text { GWh }\end{array}$ & $\begin{array}{c}\text { Total } \\
\text { GWh }\end{array}$ \\
\hline 56 & $80^{*}$ & 375,2 & 27,3 & 9.3 & 411,8 \\
\hline 7 & $4^{*}$ & - & & - & 20 \\
\hline 64 & $\mathbf{8 4 *}$ & $\mathbf{3 8 0}$ & $\mathbf{3 0}$ & $\mathbf{1 0}$ & $\mathbf{4 3 0}$ \\
\hline
\end{tabular}

*Based on a heat value of $5 \mathrm{kwh} / \mathrm{m}^{3}$

They also do some tests with upgrading LFG to veichle fuel.

\section{SUMMARY}

A summary of all the numbers are seen in table 7 .

Table 7. LFG production and utilisation in the Nordic countries.

\begin{tabular}{|c|c|c|c|c|c|c|c|}
\hline Country & $\begin{array}{c}\text { No. of } \\
\text { plants }\end{array}$ & $\begin{array}{c}\text { LFG } \\
\mathrm{m}^{3} \times 10^{6}\end{array}$ & $\begin{array}{c}\text { Heat } \\
\text { GWh }\end{array}$ & $\begin{array}{c}\text { Electricity } \\
\text { GWh }\end{array}$ & $\begin{array}{c}\text { Flare } \\
\text { GWh }\end{array}$ & $\begin{array}{c}\text { Total } \\
\text { GWh }\end{array}$ & New plants \\
\hline Denmark & 13 & 30 & 100 & 60 & $0 ?$ & 160 & $10-15$ \\
\hline Finland & 8 & 35 & 86 & 10 & 80 & 176 & 50 \\
\hline Iceland & 1 & 1 & 0 & 0 & 6 & 6 & $3-5$ \\
\hline Norway & 34 & 60 & 19 & 11 & 270 & 300 & 40 \\
\hline Sweden & 64 & 84 & 380 & 30 & 10 & 430 & 20 \\
\hline TOTAL & $\mathbf{1 2 0}$ & $\mathbf{2 1 0}$ & $\mathbf{5 8 5}$ & $\mathbf{1 1 1}$ & $\mathbf{3 6 6}$ & $\mathbf{1 . 0 7 2}$ & $\mathbf{1 2 3 - 1 3 0}$ \\
\hline \hline
\end{tabular}

LFG is an expensive energy resource, but it is a necessary way out of the global warming problems. If LFG had to be extracted from a landfill then LFG is an important and cheap support to the energy market. 
Today (1997) the LFG deliver $700 \mathrm{GWh} /$ year to the commercial market in the Nordic countries. New technology and future LFG-plants will be able to support the energy market with $2000 \mathrm{GWh}$ /year

\section{REFERENCES}

Birkeland, Knut H. 1996. "Biogass i Norge”, Nordisk Biogaskonferens 2.-3. 10 1996, Helsingborg, Sweden - The Swedish Biogas Association.

Ettala, Matti, 1997. "LFG - landfill gas in Finland. A question list answer". Matti Ettala Oy.

Gustafsson, Ludvik E. 1997. "LFG - landfill gas in Iceland. A question list answer". Environmental and Food Agency of Iceland,

Rihm, Thomas, 1997., "LFG - landfill gas in Sweden. A question list answer". The Swedish Waste Association

Taftrup, Søren, 1997. "LFG - landfill gas in Denmark. A question list answer". Danish Energy Agency. 